\title{
The GEEP Workshop: mesocosm exposures
}

\author{
T. Bakke ${ }^{1}$, O. A. Follum ${ }^{2, *}$, K. A. Moe ${ }^{2, * *}$, K. Sørensen ${ }^{1}$ \\ ${ }^{1}$ Norwegian Institute for Water Research, PO Box 333, N-0313 Blindern, Oslo 3, Norway \\ ${ }^{2}$ Department of Marine Zoology and Marine Chemistry, Biology Institute, University of Oslo, PO Box 1064, N-0316 Blindern, \\ Oslo 3, Norway
}

\begin{abstract}
For the GEEP Workshop, 4 indoor mesocosms at the Marine Research Station Solbergstrand were stocked with equal numbers of Platichthys flesus, Carcinus maenas, Mytilus edulis, Littorina littorea and Nucula tenuis as well as subtidal soft bottom sections taken with an USNEL box corer. For 4 mo prior to the workshop, 3 of the basins were continuously exposed to a mixture of diesel oil $\left(125,32\right.$ and $6 \mu g l^{-1}$ total hydrocarbons in the water) and copper (nominal 20,5 and $0.8 \mu \mathrm{g} \mathrm{l}^{-1} \mathrm{Cu}^{2+}$ ), with the fourth mesocosm basin as a control (measured total hydrocarbons of $3 \mu \mathrm{g}^{-1}$ ). Sediment sections were sampled by corers for community faunal analysis prior to the workshop; sampling of $N$. tenuis and epifauna was carried out during the workshop
\end{abstract}

\section{INTRODUCTION}

The rationale for including a mesocosm experiment in the GEEP Workshop is discussed in Bayne et al. (1988). The main intention was to ensure the availability of material which had been exposed to defined contaminant concentrations for at least 3 mo. A mixture of hydrocarbon and metal contamination at 4 different concentrations (proportion $0: 1: 6: 24$ ) was dosed to 4 mesocosm basins, named C (control), L (low), M (medium), and $\mathrm{H}$ (high) dose respectively.

This paper describes the mesocosm experimental design, the transplantation and treatment of the organisms, and the contaminant exposures.

\section{MESOCOSMS}

The experiment was carried out over 4 mo at the Marine Research Station, Solbergstrand (MRSS), Oslofjord (see Fig. 1 of Follum \& Moe 1988), owned by the Norwegian Institute for Water Research. The indoor mesocosm facility consists of 2 main concrete enclosures, each divided into 3 basins with bottom areas from 28 to $39 \mathrm{~m}^{2}$. Water exchange rate and level can be adjusted separately in each basin. A detailed description of the mesocosm facility was given by

\footnotetext{
- Present address: Norwegian State Pollution Control Authority (SFT), PO Box 8100 Dep, N-0032 Oslo 1, Norway

- Present address: CMS, Billingstadsletten 19, N-1362 Billingstad, Norway
}

Berge et al. (1986). Four of the basins were used for the workshop. The mesocosms were supplied with seawater from a depth of $42 \mathrm{~m}$. The water level was kept at

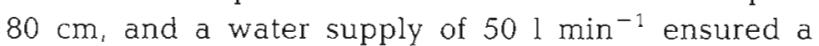
nominal exchange of water every $11 \mathrm{~h}$ in the basins.

\section{TRANSPLANTATION OF SEDIMENTS AND ORGANISMS}

Soft-bottom sections for community studies. Sediment samples for the benthic community experiment were obtained by use of a modified USNEL spade corer (Rosfelder \& Marshall 1967). By use of internal liners and specially designed transport boxes, the samples were transferred undisturbed to the mesocosm. A detailed description of corer modification and sampling technique is given by Berge et al. (1986). On 17 April, 1986,20 box samples $(47.5 \times 47.5 \mathrm{~cm}$ area, $30 \mathrm{~cm}$ deep, $10 \mathrm{~cm}$ overlying bottom water) were sampled at Bjørnehodet Bay, Oslofjord (see Fig. 1 of Follum \& Moe 1988) and transplanted to the mesocosms. Five boxes were placed in each basin at equal distances from the inlet water in order to give a similar water flow pattern across all sediment surfaces. To prevent predation and disturbance of the sediment communities from the flatfish Platichthys flesus present in the basins, thin wooden sticks ( $3 \mathrm{~mm}$ diameter) were pressed into the sediment $4 \mathrm{~cm}$ apart, close to the liner wall.

Cores taken for assessment of physical characteristics of the sediments, in July, showed the mean grain 
size across boxes to average 5.55 (range 5.3 to $5.8, \varnothing$ scale) and \% silt/clay to average 83 (range 76 to 87 ). As expected, there were no significant differences between basins, because of the random allocation of boxes to treatments.

Nucula tenuis. Knowing the approximate density of the bivalve mollusc Nucula tenuis in Bjørnehodet Bay samples (about 200 ind. $\mathrm{m}^{-2}$ ) from previous studies (Valderhaug \& Gray 1984), it was expected that a fifth core sample transplanted to each basin would contain an appropriate number of $N$. tenuis. Sampling for this box was done together with the other boxes. As a precaution, and since real density could not be determined without disturbing the sediment, grab samples taken in the same area on 15 May were sifted through 5 and $1 \mathrm{~mm}$ sieves, and the molluscs brought to the mesocosm basins. A total of 35 individual $N$. tenuis (size between 4 and $12 \mathrm{~mm}$ ) were transferred to separate boxes $(30 \times 20 \times 10 \mathrm{~cm})$ with the appropriate sediment, one for each mesocosm basin. The boxes were placed $30 \mathrm{~cm}$ above the basin floor to prevent predation and disturbance from crabs Carcinus maenas.

Platichthys flesus. From 21 to 25 April, sampling of the common flounder Platichthys flesus was carried out in 2 ways. In the daytime, the fish were caught by beach seine. In the evening, about $1000 \mathrm{~m}$ of fishing nets were set, and hauled the following morning. Fish sampling was done less than $1 \mathrm{~km}$ south and north of MRSS. Fish smaller than $15 \mathrm{~cm}$ and those with visible damage were discarded, giving a total of 144 individuals which were split equally between the mesocosms. Due to mortality of the fish (about $40 \%$ in each mesocosm) during an episode of nitrogen supersaturation of the water at the end of June, the basins were restocked, 58 tagged individuals being added. In the event, these later fish were not sampled for the workshop, there being sufficient individuals available from the original stock. The fish were fed dry pelletized fish fodder (Skretting A/S) and crushed Mytilus edulis (from a clean site) every 2 to $4 \mathrm{~d}$.

Mytilus edulis. Mussels were sampled below the low-tide mark from the pier outside MRSS on 25 April. Large aggregates of mussels were removed by hand and brought to the laboratory for length measurement. The individuals were carefully separated by cutting the byssus with scissors, and specimens between 45 and $55 \mathrm{~mm}$ selected. A total of 2000 mussels were randomly separated into 8 cages of stainless steel mesh $(80 \times 40$ $\times 10 \mathrm{~cm}), 250$ in each cage. Two cages were positioned in each basin, at equal distance from the water inlet, and raised $10 \mathrm{~cm}$ above the floor to ensure sufficient circulation along the bottom of the cages.

In an attempt to increase the particulate food for Mytilus edulis, an outdoor tank $\left(32 \mathrm{~m}^{3}\right.$, surface area
$40 \mathrm{~m}^{2}$ ) was utilised for large-scale rearing of natural phytoplankton. The water in this tank was vigorously aerated, and a stock solution of commercial non-toxic agricultural fertilizer ('Fullgjødsel D') continuously added at a rate of $26 \mathrm{~g} \mathrm{~d}^{-1}$. The culture was pumped at a rate of $51 \mathrm{~min}^{-1}$ into the main water supply to the indoor basins, with continuous replenishment from $1 \mathrm{~m}$ depth outside. Previous experience (Källqvist pers. comm.) indicated that optimal growth of such cultures ought to give the required ration of food particles in the mesocosms (ca $2 \mathrm{mg}$ dry wt $\mathrm{l}^{-1}$ ). Due to poor growth of the culture at certain times, caused by malfunction of the air compressor, it was only added to the mesocosm basins in the periods 6 to 17 June and 30 July to 20 August.

During the first $7 \mathrm{wk}$ of dosing (see below), close to $100 \%$ mortality was recorded in mussels of the $\mathrm{H}$ basin. On 13 June the survivors (24 ind.) were sampled for tissue chemical analyses, and on 18 July the $H$ basin was restocked with 500 mussels sampled from the beach $100 \mathrm{~m}$ north of the pier and treated as described above. To ensure adequate controls for the last transplants, which would endure a shorter period of contamination, 400 mussels were simultaneously transplanted to each of the other treatments (in 2 additional cages per basin).

Littorina littorea. Periwinkles were sampled by hand from the beach outside MRSS on 25 April. A total of 640 adult winkles, between 20 and $25 \mathrm{~mm}$ shell length, were randomly distributed in equal numbers on 4 stainless steel mesh cages $(35 \times 14 \times 12 \mathrm{~cm})$ with a floor of PVC. Cages were suspended, one in each basin, so that one-third of the cage was above the water surface. Winkles were fed on fresh Ulva lactuca which was renewed once a week.

Carcinus maenas. Collection of shore crabs had to be postponed until 12 May, as the sea surface temperature prior to that was below the activity threshold of the crabs $\left(8\right.$ to $\left.9^{\circ} \mathrm{C}\right)$. Using SCUBA equipment, 432 individuals were sampled by hand from the lower shore, 50 to $150 \mathrm{~m}$ north of MRSS. Crabs with carapace width above $22 \mathrm{~mm}$ were selected; they were divided between the 4 basins (108 ind. in each), ensuring a similar size frequency distribution within each basin Crabs were not caged, but the possibility of them disturbing the sediments was considered negligible The crabs utilized the same food as was offered to the flounders.

\section{WATER CONDITIONS DURING THE EXPOSURE}

Temperature was measured automatically every hour in the $\mathrm{M}$ and $\mathrm{C}$ basins. Fig. 1 shows the weekly means of readings taken at 08:00 h (when the salinity 


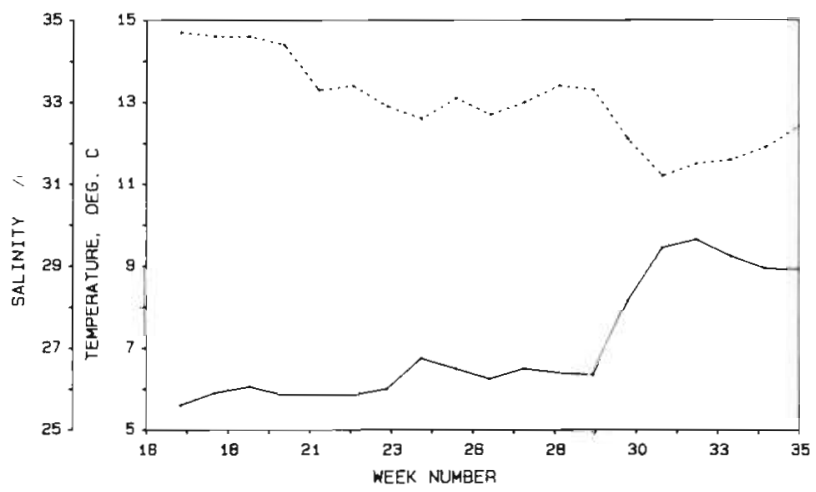

Fig. 1. Weekly mean temperature (solid line) and salinity (broken line) in mesocosms from April to August 1986

was measured) from the end of April (Week 17) to the end of August (Week 35). Readings from the basins have been averaged since the difference was not systematic and never exceeded $0.1 \mathrm{C}^{\circ}$. The temperature was fairly steady at 5.5 to $6.5^{\circ} \mathrm{C}$ from April to about 20 July. Then during $2 \mathrm{wk}$ the temperature rose to 9 to $10^{\circ} \mathrm{C}$ as the thermocline reached the depth of water intake. This temperature was maintained for the rest of the period.

Salinity was monitored daily in Basin M (Fig. 1); it decreased steadily from $35 \%$ in April to $33 \%$ at the beginning of June. A sharp decrease to $31 \%$, coincident with the temperature rise, was recorded at the end of July.

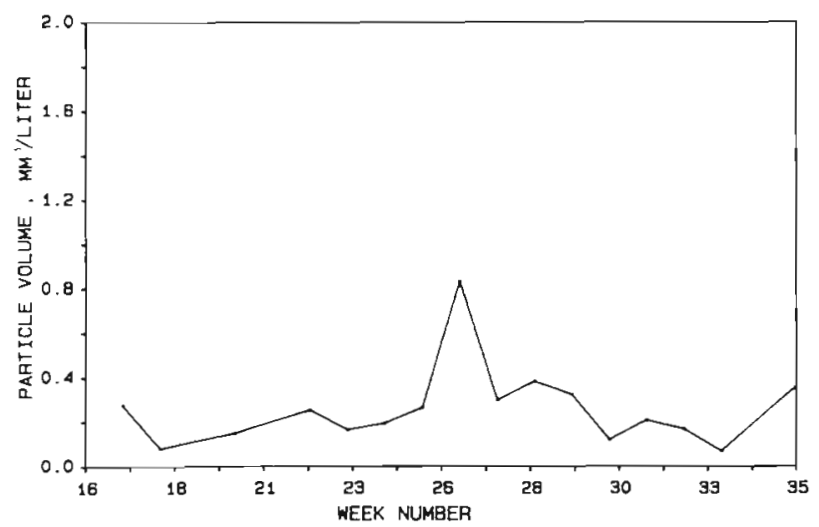

Fig. 2. Total particulate concentration in mesocosm waters from April to August. Values are means recorded in 2 basins

Particle concentration was monitored once a week in basins adjacent to $M$ and $C$. Differences between the basins were insignificant, and mean values are shown in Fig. 2. Particle concentration showed some variation, but no trend, during exposure. Particle volume was in the range 0.1 to $0.4 \mathrm{~mm}^{3} \mathrm{l}^{-1}$ for most of the experimental period.

\section{POLLUTION EXPOSURE}

From 24 April to the end of the GEEP Workshop 3 of the 4 basins were continuously exposed to a combined discharge of copper $\left(\mathrm{Cu}\left(\mathrm{NO}_{3}\right)_{2} .3 \mathrm{H}_{2} \mathrm{O}\right)$ and water accommodated fraction (WAF) of diesel oil in seawater.

The WAF was produced by continuous mixing of diesel oil and seawater (from $42 \mathrm{~m}$, preconditioned to $10^{\circ} \mathrm{C}$ ) in the volume proportion 1:4000 in a $580 \mathrm{l} \mathrm{mix}$ ing/separation system (Fig. 3). Excess oil and large oil droplets rose to the surface and were skimmed off as the WAF passed a series of baffles. Previous experience had indicated that this would give a WAF hydrocarbon concentration of about $10 \mathrm{mg} \mathrm{l}^{-1}(\mathrm{ppm})$, and at the rate of WAF production of $1000 \mathrm{ml} \mathrm{min}^{-1}$ this would produce sufficient hydrocarbons for the desired exposure.

At the distal end of the separation unit, a stock solution of $\mathrm{Cu}\left(\mathrm{NO}_{3}\right)_{2} \cdot 3 \mathrm{H}_{2} \mathrm{O}$ in distilled water $\left(3.6 \mathrm{~g} \mathrm{Cu}^{2+}\right.$ $\left.1^{-1}\right)$ was pumped into the WAF and mixed by gentle stirring to give a theoretical concentration of $\mathrm{Cu}$ in the WAF of $1.8 \mathrm{mg}^{-1}$. The Cu/WAF mixture was then pumped by separate diaphragm pumps into the main water inlets to the 3 basins, at rates $0.022,0.138$ and $0.5561 \mathrm{~min}^{-1}$ respectively for the $\mathrm{L}, \mathrm{M}$ and $\mathrm{H}$ basins, which should give concentrations close to the desired levels: 4, 25 and $100 \mathrm{\mu g} \mathrm{l}^{-1}$ for total hydrocarbons and $0.8,5$ and $20 \mu \mathrm{g} \mathrm{l}^{-1}$ for $\mathrm{Cu}^{2+}$

Routine analysis of hydrocarbons was done by fluorescence spectrometry (excitation $265 \mathrm{~nm}$, emission $322 \mathrm{~nm}$ ) on $\mathrm{n}$-hexane extracts of samples from the WAF (50 $\mathrm{ml}$, duplicate) and from the water of all 4 basins $(1000 \mathrm{ml})$. Fluorescence intensity was calibrated against a diesel oil standard to give oil units in $\mu g \mathrm{l}^{-1}$. The WAF was analysed 1 to 3 times a week, and the basins once a week (from Week 21 to 31), until the workshop started in August. Once every month, $1000 \mathrm{ml}$ samples from the WAF and from the basins were preserved with $20 \mathrm{ml}$ redistilled dichloromethane and transferred to the Institute of Marine Research, Bergen for GC/MS analysis of aromatic hydrocarbons (Klungsøyr et al. 1988).

Fig. 4 shows the fluctuation in hydrocarbon levels of the water in the basins. After subtraction of the mean background concentration $\left(3.0 \pm 0.7 \mu \mathrm{g} \mathrm{l}^{-1}\right)$ as found in the $C$ basin, mean levels for the exposure period ( $\mu \mathrm{g}$ $\mathrm{l}^{-1}, \pm \mathrm{SD}, \mathrm{n}=10$ ) were, $\mathrm{L}: 3.4 \pm 1.8, \mathrm{M}: 28.5 \pm 22.3, \mathrm{H}$ : $121.5 \pm 65.3$. Fig. 4 also shows the weekly mean 'theoretical' concentrations in $\mathrm{M}$ and $\mathrm{H}$ based on regression between simultaneous WAF and basin samples (regression was not significant for the L basin) and flow rates through the dose pumps. The variation reflects the considerable range in WAF concentration detected ( 4 to $21 \mathrm{mg} \mathrm{l}^{-1}$ ), mainly caused by erratic fluctuation in mixing efficiency.

Dose pumps were routinely adjusted to compensate 


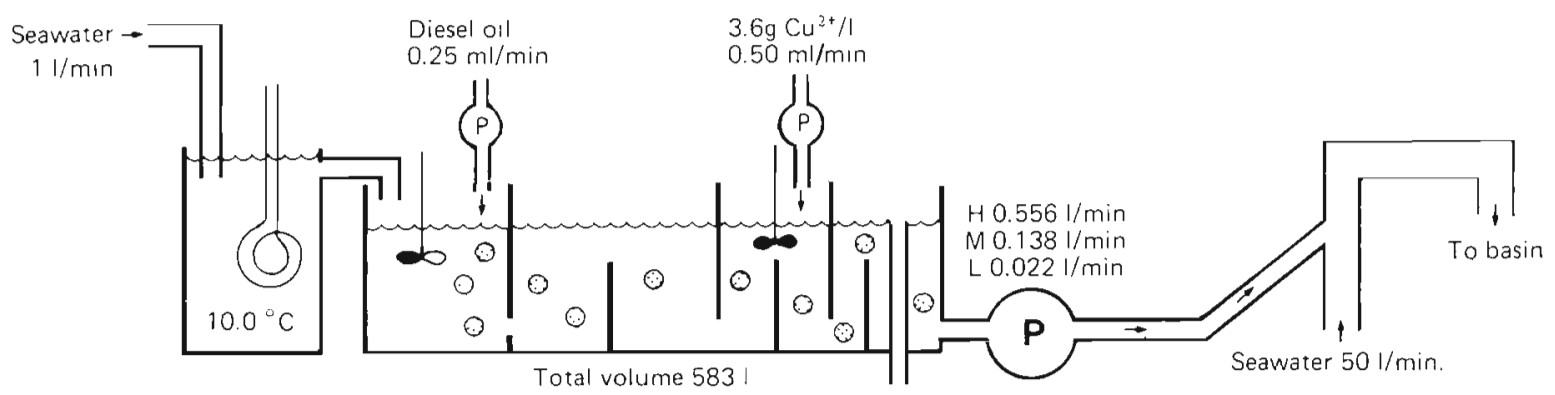

Fig. 3. Diagram of WAF and copper dosing system

for changes in WAF concentration, in particular from 23 May to 9 June. The $\mathrm{Cu}^{2+}$ stock solution was not changed accordingly, which gave a slight variation in the theoretical copper concentration (based on stock concentration and flow rates) in the basins (Fig. 5). The level of copper in the water of the basins was not monitored. One set of samples was taken on 4 August

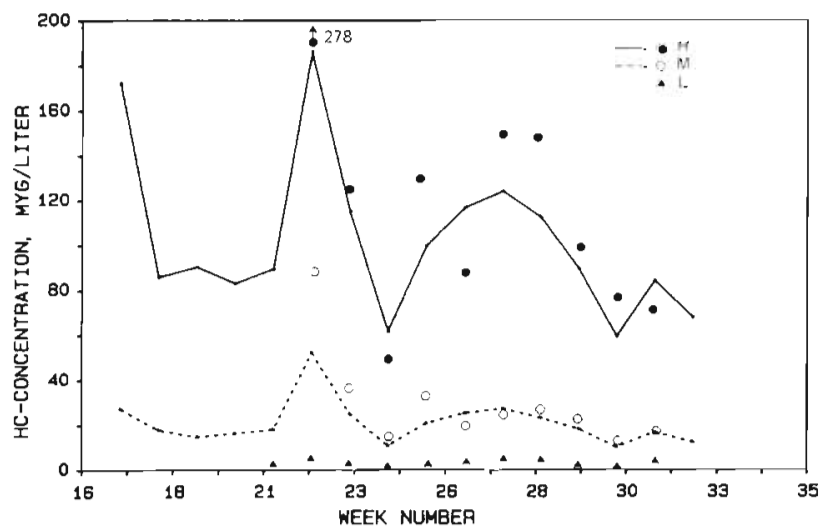

Fig. 4. Fluctuation in total hydrocarbon concentration in water of $\mathrm{H}, \mathrm{M}$ and $\mathrm{L}$ basins after subtraction of background value for Basin C. Points: concentrations measured directly. Lines: 'theoretical fluctuation based on changes in WAF concentration and flow rates

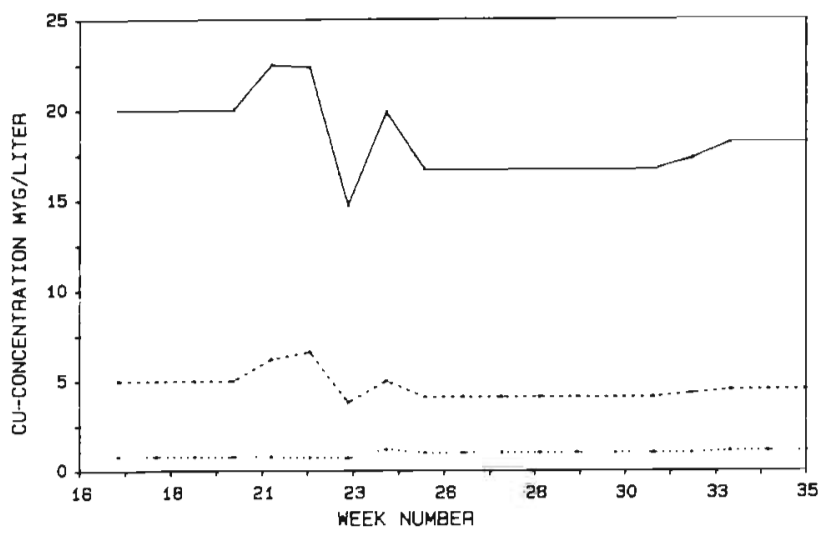

Fig. 5. Theoretical concentration of $\mathrm{Cu}^{2-}$ in water of Basins $\mathrm{H}$ (solid line), M (broken line) and L (dotted line), based on stock solution concentration and flow rates
Table 1 . Theoretical mean copper concentration $\left(\mu \mathrm{g} \mathrm{l}^{-1}, \pm \mathrm{SD}\right)$ based on stock concentration and flow rates, and results of 2 independent freon-extraction/AAS analyses of $\mathrm{Cu}$ in mesocosm water from samples taken on 4 August

\begin{tabular}{|cccc|}
\hline Basin & $\begin{array}{c}\text { Theoretical } \\
\mathrm{Cu}\end{array}$ & $\begin{array}{c}\mathrm{Cu} \\
\text { Replicate 1 }\end{array}$ & $\begin{array}{c}\mathrm{Cu} \\
\text { Replicate 2 }\end{array}$ \\
\hline $\mathrm{C}$ & - & - & - \\
$\mathrm{L}$ & - & 1.3 & 1.2 \\
$\mathrm{M}$ & $4.94 \pm 0.14$ & 4.1 & 4.8 \\
$\mathrm{H}$ & $18.33 \pm 2.14$ & 22.9 & 22.3 \\
\hline
\end{tabular}

and was analysed at NIVA for $\mathrm{Cu}, \mathrm{Zn}, \mathrm{Pb}$ and $\mathrm{Cd}$, by freon extraction methods (Danielsson et al. 1982). Copper values were close to the desired levels (Table 1). Concentrations of the other metals were within normal range.

\section{TECHNICAL MAINTENANCE AND SAMPLING}

Contaminant dosing ran from 24 April to 29 August without any major interruptions. Periods when the system had to be shut off due to repairs were 27 May $(16 \mathrm{~h}), 11$ June $(1 \mathrm{~h})$, and 14 to 16 July (56 h). After the period of high fish mortality in all basins in mid-June, nitrogen supersaturation of the water was prevented for the rest of the exposure period by lifting the inlet pipelines above the surface to ensure cascading of the seawater into the basin. Significant evaporation of hydrocarbons due to cascading could not be detected.

\section{SAMPLING PROGRAM}

An event timetable for the mesocosm experiment, including sampling protocols, is given in Table 2. Subsamples from the sediment communities were taken using external core-liners to prevent collapsing of the sediment surface and changes in sediment stratification. Sampling of epifauna was performed in the second week of the workshop (one basin each day) with 
Table 2. Timetable for the mesocosm experiment at Solbergstrand

\begin{tabular}{|c|c|c|}
\hline Date (1986) & Event & Details of stocking and sampling \\
\hline 17 Apr & $\begin{array}{l}\text { Undisturbed sediment sections from Bjornehodet Bay } \\
\text { transported to basins }\end{array}$ & 20 box cores (each $0.23 \mathrm{~m}^{2}$ ), 5 to each basin \\
\hline $21-25 \mathrm{Apr}$ & $\begin{array}{l}\text { P. flesus, } M \text { edulis and L. littorea collected at Solberg- } \\
\text { strand and placed in basins }\end{array}$ & $\begin{array}{l}\text { Per basin: } 36 \text { flounder, } 2 \text { cages of mussels ( } 250 \text { in } \\
\text { each), } 1 \text { cage of winkles ( } 160 \text { ) }\end{array}$ \\
\hline 24 Apr & $\begin{array}{l}\text { Dosing of basins with copper and WAF diesel oil } \\
\text { commenced and continued until end of workshop } \\
\text { (weekly fluorescence and monthly GC/MS hydrocar- } \\
\text { bon analysis of water) }\end{array}$ & $\begin{array}{l}\text { Nominal dose }\left(\mathrm{H} \text { basin) of } 100 \mu \mathrm{g} \mathrm{l}^{-1} \text { total hydrocar- }\right. \\
\text { bons, } 20 \mu \mathrm{g} \mathrm{l}^{-1} \mathrm{Cu} \text {, at strengths } \\
100 \%: 25 \%: 4 \% .0 \% \text { in H, M, L. C }\end{array}$ \\
\hline 12 May & Stocking of C. maenas from Solbergstrand & 180 crabs per basin \\
\hline 15 May & Stocking of $N$. tenuis from Bjørnehodet Bay & 1 box ( 35 individuals) per basin \\
\hline 16 May & $\begin{array}{l}\text { First chemical sampling of sediments and mussels in } \\
\text { the control basin for PAH analysis (at Bergen) }\end{array}$ & $\begin{array}{l}2 \text { cores ( } 33.2 \mathrm{~cm}^{2}, 3 \mathrm{~cm} \text { deep) from } 4 \text { boxes and } 2 \text { pools } \\
(10 \text { mussels), from C }\end{array}$ \\
\hline 29 May & $\begin{array}{l}\text { Meiofaunal cores sampled from all basins with sub- } \\
\text { samples for bacteria }\end{array}$ & $\begin{array}{l}4 \text { cores from each basin (only bacteria analysed quan- } \\
\text { titatively) }\end{array}$ \\
\hline 13 Jun & $\begin{array}{l}\text { Mid-term chemistry samples taken for PAH analysis } \\
\text { in mussels and sediments (at Bergen) and metals in } \\
\text { mussels (at Oslo) }\end{array}$ & $\begin{array}{l}\text { Per basin: } 1 \text { core in } 2 \text { boxes and } 2 \text { pools of mussels for } \\
\text { PAH, } 1 \text { pool for metals (including all remaining } \mathrm{H} \\
\text { basin mussels) }\end{array}$ \\
\hline $7 \mathrm{Jul}$ & $\begin{array}{l}\text { Final chemistry samples of sediment for PAH and } \\
\text { metals; also PAH for mussels from Solbergstrand field } \\
\text { population, prior to restocking }\end{array}$ & $\begin{array}{l}\text { Per basin: } 1 \text { core from } 2 \text { basins for PAH, } 1 \text { core } \\
\left(26.4 \mathrm{~cm}^{2}, 1 \mathrm{~cm} \text { deep) from } 4 \text { boxes for metals; } 2 \text { pools }\right. \\
\text { of mussels for PAH }\end{array}$ \\
\hline $10 \mathrm{Jul}$ & $\begin{array}{l}\text { Main meiofaunal and bacterial sampling for the work- } \\
\text { shop; cores despatched for analysis (in Plymouth and } \\
\text { Dartmouth) }\end{array}$ & $\begin{array}{l}\text { Per basin: } 4 \text { cores }\left(28 \mathrm{~cm}^{2}, 8 \mathrm{~cm} \text { deep) from each of }\right. \\
4 \text { boxes, pooled within boxes (16\% subsampled); } \\
\text { bacteria from } 4 \text { boxes }\end{array}$ \\
\hline $18 \mathrm{Jul}$ & $\begin{array}{l}\text { All basins restocked with additional mussels following } \\
\text { gross mortality in H basin by } 13 \text { Jun }\end{array}$ & $400-500$ per basin, in 2 extra cages \\
\hline $21 \mathrm{Jul}$ & $\begin{array}{l}\text { Main macrofaunal sampling for the workshop, cores } \\
\text { analysed at Oslo }\end{array}$ & $\begin{array}{l}\text { Per basin: } 2 \text { cores }\left(68 \mathrm{~cm}^{2}, 30 \mathrm{~cm} \text { deep) from each of }\right. \\
4 \text { boxes }\end{array}$ \\
\hline $29 \mathrm{Jul}$ & Remaining sediment sieved for large macrofauna & Top $10 \mathrm{~cm}$ of each box sieved through $5 \mathrm{~mm}$ \\
\hline 4 Aug & $\begin{array}{l}\text { Final chemical sampling of mussels and crabs for PAH } \\
\text { and metals }\end{array}$ & $\begin{array}{l}\text { Per basin: } 2 \text { pools each of original and restocked } \\
\text { mussels, and crabs ( } 4 \text { per pool) }\end{array}$ \\
\hline $8-11$ Aug & Participants arrive for workshop & \\
\hline 11. Aug & $\begin{array}{l}\text { H dose mussels sampled for biological analysis and } \\
\text { transported to Oslo }\end{array}$ & $\begin{array}{l}\text { Total collection of animals divided randomly between } \\
\text { participants }\end{array}$ \\
\hline $18 \mathrm{Aug}$ & $\begin{array}{l}\text { Mussels, flounder, winkles, crabs and Nucula sam- } \\
\text { pled from the M basin, for biological analysis (and } \\
\text { metal chemistry on fish) }\end{array}$ & $\begin{array}{l}\text { Participants working on responses and metal chemis- } \\
\text { try in fish all used the same individuals }\end{array}$ \\
\hline 19 Aug & All species sampled for $\mathrm{C}$ basin & \\
\hline $20 \mathrm{Aug}$ & All species sampled for L basin & \\
\hline 21 Aug & $\begin{array}{l}\text { All species sampled for H basin (except mussels and } \\
\text { Nucula) }\end{array}$ & None of 35 Nucula stocked in $\mathrm{H}$ basin survived \\
\hline 26 Aug & $\begin{array}{l}\text { Coding of material revealed and chemical data made } \\
\text { available for final discussions }\end{array}$ & \\
\hline
\end{tabular}

the exception of Mytilus edulis from the $\mathrm{H}$ basin, sampling of which was brought forward $10 \mathrm{~d}$ to avoid any risk of significant mortalities and consequent shortfall in material available to participants. When sampling a basin for epifauna, the water of a single basin was drained to a depth of $10 \mathrm{~cm}$, and all individuals could thereby be easily picked out by hand within $1 \mathrm{~h}$. All samples were coded before being handed over to workshop participants, with the exception of $\mathrm{H}$ dose mussels, which were the only samples not analysed 'blind' at the workshop. Packing and transport of samples to the University of Oslo followed the same procedure as for field samples (Follum \& Moe 1988).

Acknowledgements. We thank the skipper and co-skipper of F/F Trygve Braarud, T. Tønnesen and I. Dyrkorn for their help; M. Aschan, J. Sveistrup, P. Thome and M. Walday for assistance during sampling and transplantation; $B$. Silde for hydrocarbon and particle analysis; and R. Beba for metal analysis. We are also grateful for assistance from the technical staff at Solbergstrand, E. Johannesen and O. Pettersen. 


\section{LITERATURE CITED}

Bayne, B. L., Clarke, K. R., Gray, J. S. (1988). Background and rationale to a practical workshop on biological effects of pollutants. Mar. Ecol. Prog. Ser. 46: 1-5

Berge, J. A., Schaanning, M., Bakke, T., Sandøy, K., Skeie, G. M., Ambrose, W. G., Jr (1986). A soft bottom sublittoral mesocosm by the Oslofjord: description, performance, and examples of applications. Ophelia 26: 31-54

Danielsson, L., Magnusson, B., Westerlund, S., Zhany, K. (1982). Trace metal determinations in estuarine waters by electrothermal atomic absorption spectrometry after extraction of dithiocarbamate complexes onto freon. Analytica chim. Acta 144: 183-188
Follum, O. A., Moe, K. A. (1988). The GEEP Workshop: field sampling. Mar Ecol. Prog. Ser. 46: 7-12

Klungseyr, J., Wilhelmsen, S., Westrheim, K., Saetvedt, E., Palmork, K. H. (1988). The GEEP Workshop: organic chemical analyses. Mar. Ecol. Prog. Ser. 46: 19-26

Rosfelder, A. M., Marshall, N. F. (1967). Obtaining large undisturbed and orientated samples in deep waters. In: Richards, A. R. (ed.) Marine geotechnique. Univ. of Illinois Press, Illinois, p. 243-263

Valderhaug, V.A., Gray, J. S. (1984). Stable macrofauna community structure despite fluctuating food supply in subtidal soft sediments of Oslofjorden, Norway. Mar. Biol. 82: $307-322$ 